prykordonnykiv [Formation of professional competence of future officers-border guards]. Extended abstract of candidate's thesis. National Academy of the State Border Guard Service of Ukraine named after Bohdan Khmelnytskyi, Khmelnytskyi, 20 p. [in Ukrainian].

4. Mashtaler, A. M. (2016). Rozvytok profesiinoi kompetentnosti ofitseriv-prykordonnykiv u systemi pidvyshchennia kvalifikatsii zasobamy dystantsiinoho navchannia [Development of professional competence of border guards officers in the system of professional development by means of distance learning]. Extended abstract of candidate's thesis. National Academy of the
State Border Guard Service of Ukraine named after Bohdan Khmelnytskyi, Khmelnytskyi, 16 p. [in Ukrainian].

5. Torichnyi, O. V. (2016). Formuvannia profesiinoi kompetentnosti maibutnikh ofitseriv-prykordonnykiv zasobamy proektnoi diialnosti [Formation of professional competence of future officers-border guards by means of project activity] [Electronic resource]. Bulletin of the National Academy of the State Border Guard Service of Ukraine, Vol. 1 file://C: /Users/ Admin/Downloads/Vnadped_2016_1_10.pdf], 16 p. [in Ukrainian].

Стаття надійшла до редакції 01.02.2018

УДК 001.12:37.013.32

Світлана Бабійчук, кандидат педагогічних наук Національний педагогічний університет імені М.П. Драгоманова, м. Киӥв

\title{
НАУКОВА ОСВІТА ЯК ПЕДАГОГІЧНИЙ КОНЦЕПТ
}

У статті розглянуто основні ідеї впровадження наукової освіти у шкільну практику. Представлено історію становлення наукової освіти на прикладі США та Великої Британії. Розглянуто тлумачення поняття “наукова освіта" закордонними та украӥнськими вченими. Висвітлено роль та місце наукової освіти у діяльності ЮНЕСКО. Базуючись на прачях професора Вінн Гарлен описано 10 принципів впровадження концепту наукової освіти в школі. Визначено, щэо метою впровадження наукової освіти в школі є навчити учня мислити як науковець та новатор.

Ключові слова: наукова освіта, учень, педагогічний концепт, педагогічний приниип, наукове дослідження.

Jim. 7.

Svitlana Babiychuk, Ph.D.(Pedagogy), National Mukhaylo Drahomanov Pedagogical University, Kyiv

\section{SCIENCE EDUCATION AS A PEDAGOGICAL CONCEPT}

The author considers the main ideas of introducing the science education into the school practice. The article reviewed the history of science education developing in the example of the United States of America and Great Britain. The explanation of the concept "science education" by foreign and Ukrainian scientists is considered. Science education should enhance learners' curiosity, wonder and questioning, building on their natural inclination to seek meaning and understanding of the world around. Science should be introduced and encountered by school students as an activity that is carried out by people including themselves. Their personal experiences of finding out and of making connections between the new and previous experiences not only bring excitement and personal satisfaction but also the realisation that they can add to their knowledge through active inquiry. Both the process and product of scientific activity can evoke a positive emotional response, which motivates further learning.

The role and place of science education of the UNESCO are highlighted. In a world that is increasingly shaped by science and technology, the UNESCO recognizes this and has made it its mission to not only spread education but to make an interest in the Sciences a prominent and lasting feature wherever it is offered.

Based on Professor Wynne Harlen's research, the author describes 10 principles of implementation of the concept of science education at school. It is determined that the purpose of the introduction of science education at school is to teach a pupil to act and think as a scientist and innovator. Undertaking scientific inquiry gives students the enjoyment of finding out for themselves and initiates appreciation of the nature of scientific activity, of the power and the limitations of science.

Keywords: science education, a pupil, pedagogical concept, a pedagogical principle, scientific research.

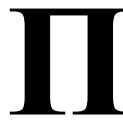

остановка проблеми у загальному вигляді та ії̈ зв'язок із важливими науковими чи практичними завданнями. Розвиток наукових знань направлений та виникає із потреби покращити умови існування людини. Наукові знання $є$ i

(C)

С. Бабійчук, 2018 результатом і засобом вивчення науки в школі. Історія вивчення науки у школі у таких економічно розвинених країнах, як США, Канада, Велика Британія, Швеція та ін., налічує більше 100 років. Закладені в школі основи наукового знання сприяють навчанню та вихованню нової генерації 
дослідників, вчених та новаторів, які сприяють економічному розвитку країн та еволюції наукової думки.

Аналіз основних досліджень і публікацій. Дослідженням імплементації наукової освіти в сучасний навчально-виховний процес займаються С. Довгий, М. Гальченко, Ю. Гоцуляк. Витоки педагогічної думки через філософські школи досліджують В. Андрущенко, В. Вашкевич, Т. Андрущенко, В. Огнев'юк та ін.

Метою статті $\epsilon$ визначення ролі наукової освіти, як педагогічного концепту у шкільній освіті.

Виклад основного матеріалу дослідження. Наукова освіта як педагогічний концепт має на меті виплекати нову генерацію науковців, базуючись на певних методиках, методах, формах навчання та навчальному змісті. Вчитель не виконує роль єдиного джерела інформації, з метою передати ii учням, а є наставником, який курує комплексоми учнівських досліджень. Кінцевим результатом такого навчання має бути новий тип мислення в учнів, коли наука сприймається як інструмент, засіб для вирішення практичних проблем конкретної людини, сім’ї, міста, держави чи більш глобальних масштабів.

Сьогодні термін "science education" (наукова освіта) часто зустрічається в англомовній педагогічній літературі. Більшість авторитетних наукових часописів, які публікують результати впровадження наукової освіти в практику мають давню історію, так “International Journal of Science Education” (Міжнародний журнал наукової освіти), імпакт-фактор якого у 2016 році становив 1,24, заснований у 1979 році (тоді він носив назву “Свропейський журнал наукової освіти”); перший випуск наукового журналу "Studies in Science Education” (Навчання в науковій освіті) вийшов друком у 1974 році; найбільш цитованим науковим журналом, де публікуються результати досліджень 3 наукової освіти, $є$ однойменний "Science Education" (Наукова освіта), перший примірник якого надруковали ще у 1916 році.

Першим вчителем науки був Вільям Шарп британський хірург та лікар. У 1850 році за його ініціативою та аргументацію наука викладалася, як звичайний шкільний предмет у школі Рагбі (графство Ворикшир). Наступним важливим етапом становлення науки як шкільного предмету, стала публікація у 1867 році звіту Британської академії з популяризації науки (з 2009 року відома як Британська наукова асоціація) через навчання “чистої науки” та формування наукового типу мислення в учнів.

Перспективність та необхідність вивчення науки не викликало сумнівів у тогочасних педагогічних колах, проте першочерговою проблемою, 3 якою стикалася ця ідея, це відсутність кваліфікованих та підготовлених до читання такого предмету вчителів. Одним з двох ключових рішень цієї проблеми було заснування першої Лондонської шкільної ради у 1870 році, де обговорювали зміст шкільних програм, в тому числі розроблялася програма 3 вивчення науки. Другим рішенням стала організація курсів перепідготовки для вчителів, де б вони отримали кваліфікацію вчителя з науки.

Ще одним центром формування науки, як шкільного предметує Сполучені Штати Америки. До 1890-их років науки не існувало, як окремого шкільного предмету, проте частково її зміст вивчався в інших курсах. Визначення, які ж знання будуть необхідними теперішнім школярам через 10-20 років, мали відобразитися у шкільній програмі, яка того часу формувалася у дискусії двох педагогічних ідеологій - загальногромадянської та перед професійної. Результатом конференції 1892 року стало формування Комітету Десяти, які обиралися Національною Асоціацією освіти і мали повноваження організовувати майбутні збори та призначали робочі групи 3 питань змісту предметів, які вивчалися в американських загальноосвітніх навчальних закладах, в тому числі і науки. За даними Комітету Десяти, метою середньої школи було підготувати всіх учнів до успішного життя, благополуччя та як наслідок добробуту усього суспільства, а також підготувати до успішного навчання в коледжі.

Отже, наукова освіта - це педагогічний концепт, метою якого $є$ популяризація та вивчення науки серед учнів. Концепт наукової освіти охоплює такі сфери, як науковий контент, наукові методи, засоби та принципи, деякі суспільні науки, а також педагогічні технології та методики [5]. 3 погляду українських науковців - М. Гальченка та Ю. Гоцуляка, наукова освіта грунтується на автономності учня у навчально-виховному процесі та передбачає самостійний пошук і виконання освітніх завдань учнем, як окремих проектів та досліджень, під керівництвом учителя-консультанта $[7,5]$.

Традиційно вивчення наукової освіти у школах (США, Канада, Велика Британія та ін.) здійснюється у всьому курсі освіти за системою K-12 і базується на таких предметах як математика, фізика, інженерія, хімія та мікротехнології [1].

Сьогодні координація впровадження та розвитку концепту наукової освіти у світі здійснюється, в тому числі, силами Організації 
Об’єднаних Націй $з$ питань освіти, науки і культури (ЮНЕСКО). У 1972 році ЮНЕСКО сприяло створенню Міжнародної Ради Асоціацій 3 Наукової Освіти (International Council of Associations for Science Education (ICASE), метою якої $є$ поширити та вдосконалити вивчення наукової освіти у всьому світі. Сьогодні ICASE це велика мережа наукових асоціацій вчителів, установ, фондів та компаній з більше ніж 75 країн, в тому числі і Україна, які працюють разом, щоб популяризувати науку у всьому світі [2].

Наукову освіту можна розглядати як практичний підхід до філософії ЮНЕСКО [3]. Сприяти вивченню науки на всіх рівнях освіти та підвищення рівня наукової грамотності суспільства в цілому є фундаментальною основою для наукового та технологічного розвитку будьякої країни. Особливий акцент робиться на заохоченні молодих людей, особливо дівчат, займатися наукою. Наукова освіта була одним із пріоритетів ЮНЕСКО з моменту її створення [4]. Наукова освіта є ключовим елементом усіх програм ЮНЕСКО в галузі науки, освіти та комунікації. Ці програми координуються через Міжгалузеву Платформу Наукової Освіти $[1 ; 4]$.

Розуміння того, що сучасний випускник школи повинен володіти не лише базовими знаннями з науки, але й навичками створювати нові винаходи та робити відкриття пропагується не лише ЮНЕСКО, а й національними науковими товариствами та організаціями.

На даний момент Європа стикається 3 дефіцитом спеціалістів, обізнаних у науковій сфері, на всіх рівнях суспільства і економіки. За останні десятиліття спостерігається збільшення кількості учнів і студентів, які отримують наукові спеціальності після закінчення навчання. Водночас, не помічено як паралельного підвищення кількості випускників, зацікавлених у побудові наукової кар'єри, так і зростання інноваційної діяльності у науковій сфері та належної кількості відповідних підприємницьких ініціатив $[5,6]$.

3 педагогічної точки зору, одним із важливих питань $є$ базові принципи впровадження концепту наукової освіти у школі. Професор Ліверпульського універистету - Вінн Гарлен визначила 10 принципів наукової освіти [6].

1. Шкільне навчання повинно буги зосереджене на створенні умов, коли учні зацікавлені та вмотивовані здійснювати наукові дослідження, щоб розуміти та пояснити природні процеси та явища.

2. Основною метою наукової освіти $\epsilon$ виховання активного громадянина, через участь учнів у прийнятті рішень, що впливають на їхнє власне благополуччя, добробут суспільства та навколишнього середовища.

3. Наукова освіта має декілька цілей. Вона повинна бути спрямована на розвиток в учнів: розуміння “великих ідей” науки, які включають ідеї науки та ідеї про науку; наукових навичок, пов'язаних зі збором та використанням даних; неупередженої позиції науковця.

4. Повинна бути чітка узгодженість у досягненні цілей наукової освіти на основі ретельного аналізу наукових концепцій, актуальних наукових досліджень, які можна навчати у школі та їх відповідність віковим особливостям учня.

5. Прогрес у вивченні наукових ідей повинен бути результатом опрацювання тем, що цікавлять учнів, та $є$ актуальними у їхньому житті.

6. Навчання повинно базуватися на актуальних наукових та педагогічних ідеях та знаннях.

7. Усі навчальні програми з науки повинні поглиблювати розуміння наукових ідей, а також сприяти формуванню наукової позиції учня та розвитку його дослідницьких можливостей.

8. Програми навчання учнів, а також початкове навчання та підвищення кваліфікації вчителів повинні відповідати навчально-методичним методам, необхідним для досягнення цілей, викладених у Принципі 3 .

9. Оцінка має ключову роль у науковій освіті. Оцінка навчальних досягнень учнів та оцінка індивідуального прогресу учня повинні відображати рівень досягнення освітніх цілей.

10. Працюючи над досягненням цілей наукової освіти, школа повинна сприяти співпраці між вчителями та зацікавленими громадянами, в тому числі учених.

Наукова освіта має посилювати зацікавленість учнів, базуючись на їхню природну схильність шукати сенс та розуміння навколишнього світу. Їхнє особисте дослідження, виявлення та встановлення зв'язків між новими знаннями та досвідом можуть викликати позитивну емоційну реакцію, яка мотивує до подальшого навчання. Вивчення науки підтримує розуміння тї як важливого людського прагнення до пізнання істини, шляхом систематичного збору даних їх аналізу та інтерпретації. У цьому контексті ми вважаємо що впровадження концепту наукової освіти в школі дозволить виховати багатогранну особистість, через формування дослідницьких компетентностей.

Висновки. Наукова освіта покликана культивувати учнівську допитливість, навчити милити як новатор і вчений, зміщуючи освітній 
фокус від вивчення окремих фактів та теорій до формування навичок як застосувати ці знання в майбутньому для вирішення конкретних завдань. Перспективними напрямками подальших досліджень $\epsilon$ вивчення досвіду окремих країн із впровадження наукової освіти в школу та можливість імплементувати його в українських реаліях.

\section{ЛITEPATУРA}

1. Basic Sciences Education [Електронний ресурс] // UNESCO - Режим доступу до ресурсу: http://www.unesco.org/new/en/natural-sciences/ special-themes/science-education/basic-sciences/.

2. International Council of Associations for Science Education [Електронний ресурс] - Режим docmyny до pecypcy: http://www.icaseonline.net/.

3. Science Education [Електронний ресурс] // UNESCO - Режим доступу до ресурсу:http:// www.unesco.org/new/en/natural-sciences/specialthemes/science-education/.

4. Science Education Programme [Електронний pecypc] // UNESCO - Режим доступу до pecypcy:http://www.unesco.org/new/en/naturalsciences/special-themes/science-education/aboutthe-programmel.

5. Sience Education for Responsible Citizenship [Електронний ресурс] - Режим доступу до pecypcy: http://ec.europa.eu/research/swafs/pdf/ pub_science_education/KI-NA-26-893-EN-N.pdf.

6. Wynne H. Principles and big ideas of science education [Електронний ресурс] / Harlen Wynne // Association for Science Education. - 2010. - Режим docmyny до pecypcy: www.interacademies.org/ File.aspx? $i d=25103$.

7. Гоиуляк Ю. В. Наукова освіта в Украӥні: теоретичний та нормативно-правовий контекст / Ю. В. Гочуляк, М. С. Гальченко // Освіта та розвиток обдарованої особистості. - 2016. - № 4. - C. 5-11.

\section{REFERENCES}

1. Basic Sciences Education. Retrieved from: http:/ /www.unesco.org/new/en/natural-sciences/specialthemes/science-education/basic-sciences/ [in English].

2. International Council of Associations for Science Education. Retrieved from: http://www.icaseonline.net/ [in English].

3. Science Education. Retrieved from: http:// www.unesco.org/new/en/natural-sciences/specialthemes/science-education/ [in English].

4. Science Education Programme. Retrieved from: http://www.unesco.org/new/en/natural-sciences/ special-themes/science-education/about-theprogramme/ [in English].

5. Sience Education for Responsible Citizenship. Retrieved from: http://ec.europa.eu/research/swafs/ $\mathrm{pdf} /$ pub_science_education/KI-NA-26-893-EN-N.pdf [in English].

6. Wynne, H. Principles and big ideas of science education. Retrieved from: www.interacademies.org/ File.aspx?id=25103 [in English].

7. Gotsulyak, Yu.V. \& Galchenko, M. S. (2016). Science education in Ukraine: theoretical and normative-legal context. Education and development of gifted personality, no.4, pp. 5-11. [in Ukrainian].

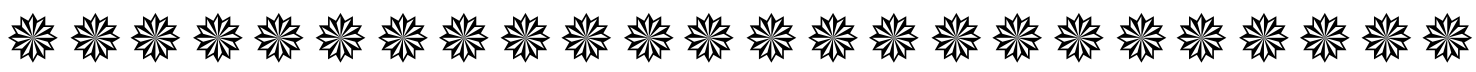

"Лериа прикмета освіти - знати минуле і сучасне свого народу".

Іван Франко

украйнський поет, письменник

"Яқщо бажаєте досягти в житті успіху, зробіть наполегливість своїм қращим другом, досвід - мудрим радником, обережність - стариим братом, а надію ангелом-хоронителем".
Dжозеб Еддісон
англійський писъменник-есеїст, драматург, публіиист та похітичний діяч

“Единою межею наших завтрашніх звершень стануть наші сьогоднішні сумніви". Франклін Фелано Рузвельт 32-ий президент США 1933-45, демоқрат

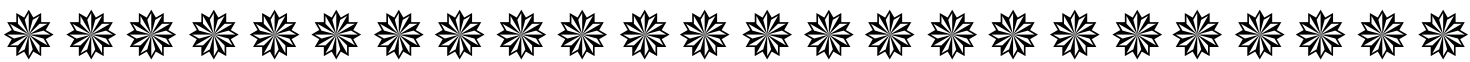

